\title{
Nilai Tukar Petani dan Pola Konsumsi Rumah Tangga (Studi Kasus: Petani Tanaman Pangan dan Hortikultura di Kecamatan Sabak Timur Kabupaten Tanjung Jabung Timur)
}

\author{
Evi Adriani ${ }^{1 *}$, Hasminidiarty ${ }^{2}$, Ali Fahmi ${ }^{3}$ \\ ${ }^{1,2}$ Fakultas Ekonomi Universitas Batanghari \\ ${ }^{3}$ Fakultas Ekonomi dan Bisnis Universitas Muhammadiyah Jambi \\ "Correspondence email: adrianievi@yahoo.co.id
}

\begin{abstract}
The structure of household expenditure describe the purchasing power of households. For farmer households, their purchasing power is reflected in the exchange rate of the farmers (NTP). NTP describe the higher purchasing power is also higher, which will influence the consumption patterns of farmers. This study aims to: 1) describe the characteristics of farmers, 2) calculate the exchange rate farmers (NTP) and 3) to analyze the pattern of household consumption and horticulture crop farmers in the Eastern District of Muara Sabak. Primary data type with purposive sampling method, were analyzed with descriptive methods in the form of table distibusi frequency and cross tabulation. The results showed: 1) 82.5\%farmers belonging to the productive age, the program received by farmers only PAJALELE program, the number of household members mostly 3-4 people and no one including smallholders to own property ownership status of more than 50\%. Crops planted by farmers are rice, corn and beans (soy and peanut) and horticultural chili, cucumber, beans, cabbage, eggplant, kale, dragon fruit and litchi. A total of 95\% had a second job, the main income of the average farmer Rp. 14,453,162 per growing season or Rp. 3,613,290.5 per month, the average revenue side Rp.2.658.667; 2)NTP did not show a significant difference to household NTP (NTPRP) respectively are 1.47045 and 1.67339 with NTP value distributions for each respondent so lame; 3) The consumption pattern comprising farmers of food and non food consumption in which the average number of non-food consumption is greater than consumption of food. Food consumption is dominated by rice, while non contribute most to the consumption of processed foods. Consumption expenditure for transportation of proportion is highest among the other non-food consumption. Advisable to socialize and educate farmers about the smart and healthy consumption patterns that consumption of great benefit to the quality of human resources and increase agricultural production.
\end{abstract}

Keyword: NTP, consumption, household expenditures

\section{Pendahuluan}

Pelaksanaan pembangunan pertanian pada dasarnya ditujukan untuk meningkatkan kesejahteraan masyarakat terutama petani. Oleh karena itu, dalam setiap tahap kegiatan pembangunan pertanian, kesejahteraan petani selalu menjadi tujuan pembangunan. Melalui berbagai kebijakan dan program pembangunan pertanian yang dilaksanakan, pemerintah telah berupaya meningkatkan produksi pertanian dalam rangka menjaga stabilitas pasokan bahan pangan dan meningkatkan pendapatan/kesejahteraan petani. Pendapatan memiliki peranan yang penting karena menyangkut daya beli rumah tangga. Rumah tangga dengan tingkat pendapatan tinggi akan dapat memenuhi kebutuhan hidupnya dibandingkan dengan rumah tangga dengan tingkat pendapatan rendah. Pendapatan tersebut pada akhirnya mempengaruhi tingkat dan pola konsumsi masyarakat secara umum. Pola konsumsi rumah tangga tersebut akan menggambarkan kualitas hidup rumah tangga dan menggambarkan tingkat kesejahteraan rumah tangga. Rumah tangga dengan pangsa pengeluaran pangan yang lebih tinggi tergolong rumah tangga dengan tingkat kesejahteraan relatif rendah dibandingkan dengan rumah tangga dengan proporsi pengeluaran untuk pangan yang rendah (BPS,1996; Rachman, HPS, 2001 dalam Handewi dkk, 2004).

Simatupang dan Maulana (2008) menyatakan bahwa penanda kesejahteraan yang unik bagi rumahtangga tani praktis tidak ada, sehingga NTP menjadi pilihan satu-satunya dalam menilai tingkat kesejahteraan petani. Nilai tukar petani menggambarkan tingkat daya tukar/daya beli petani terhadap produk yang dibeli/dibayar petani yang mencakup konsumsi dan input produksi yang dibeli. Semakin tinggi nilai tukar petani, semakin baik daya beli petani terhadap produk konsumsi dan input produksi tersebut, dan selanjutnya akan mempengaruhi kepada pola konsumsi masyarakat (petani). Dengan demikian, NTP merupakan salah satu indikator relatif tingkat kesejahteraan petani. Semakin tinggi NTP, relatif semakin sejahtera tingkat kehidupan petani (Silitonga, 1995; Sumodiningrat, 2001; Tambunan, 2003; BPS, 2006; Masyhuri, 2007). Secara umum kebutuhan konsumsi/pengeluaran rumah tangga adalah berupa kebutuhan pangan dan kebutuhan non pangan di mana kebutuhan keduanya berbeda. Pada kondisi pendapatan yang terbatas, lebih dahulu mementingkan kebutuhan konsumsi pangan. Hal ini sesuai dengan hukum Engel yang mengemukakan bahwa kelompok masyarakat dengan pendapatan rendah akan menggunakan sebagian besar pendapatannya untuk memenuhi kebutuhan makanan terlebih dahulu. Seiring dengan pergeseran dan peningkatan pendapatan, proporsi pola pengeluaran untuk pangan akan menurun dan pengeluaran untuk kebutuhan non pangan akan meningkat (Sugiarto, 2008). 
Pembangunan pertanian berorientasi ke arah perbaikan kesejahteraan pelaku pembangunan, khususnya petani yang bergerak di bidang budidaya tanaman pangan dan tanaman hortikultura. Salah satu indikator untuk melihat tingkat kesejahteraan keluarga adalah melalui struktur pengeluaran rumah tangga. Rumah tangga dengan pangsa pengeluaran pangan yang lebih tinggi tergolong rumah tangga dengan tingkat kesejahteraan relatif rendah dibandingkan dengan rumah tangga dengan proporsi pengeluaran untuk pangan yang rendah (BPS,1996; Rachman, HPS, 2001 dalam Handewi dkk, 2004). Konsumsi adalah pembelanjaan barang dan jasa oleh rumah tangga, mencakup pembelanjaan rumah tangga pada barang yang tahan lama, kendaraan dan perlengkapan dan barang tidak tahan lama seperti makanan dan pakaian (Mankiw, 2006). Pola konsumsi ialah kebutuhan manusia baik dalam bentuk benda maupun jasa yang dialokasikan selain untuk kepentingan pribadi juga keluarga yang didasarkan pada tata hubungan dan tanggung jawab yang dimiliki yang sifatnya terealisasi sebagai kebutuhan primer dan sekunder (Singarimbun,1978 dalam Niken 2012). Pola konsumsi juga dapat diartikan sebagai tanggapan aktif manusia terhadap lingkungan alam maupun lingkungan sosial yang berkaitan erat dengan kehidupan kebudayaan masyarakat, dimana tanggapan aktif yang ada bisa dalam bentuk pemenuhan kebutuhan primer dan sekunder (Moehadi,dkk, 1981, dalam Tika (2010). Dengan demikian maka pola konsumsi dapat didefinisikan sebagai suatu kondisi sifat kecenderungan pengeluaran keluarga yang dipergunakan untuk kebutuhan primer maupun sekunder, pangan dan non pangan, yang merupakan tanggapan manusia terhadap lingkungan dan berkaitan dengan kehidupan kebudayan masyarakat yang menjadi ciri khas dari kelompok masyarakat tersebut.

Penerimaan identik dengan tingkat kesejahteraan petani dimana salah satu indeks yang biasa dipakai untuk mencerminkannya adalah Nilai Tukar Petani (NTP). Dalam hal kemungkinan adanya kaitan antara NTP dan pola konsumsi masyarakat dengan kondisi kesejahteraan petani, maka sangat relevan untuk mengkaji mengenai gambaran nilai tukar petani (NTP) dan pola konsumsi masyarakat serta faktor-faktor yang mempengaruhi konsumsi. Penelitian ini bertujuan untuk: 1) Mendeskripsikan karakteristik petani tanaman pangan dan hortikultura di Kecamatan Muara Sabak Timur; 2) Menghitung nilai tukar petani (NTP) petani tanaman pangan dan hortikultura di Kecamatan Muara Sabak Timur dan 3) Menganalisis pola konsumsi rumah tangga petani tanaman pangan dan hortikultura di Kecamatan Muara Sabak Timur.

\section{Metode}

Jenis data menurut Sugiyono (2011) terdiri dari data kuantitatif dan data kualitatif. Penulis disini menggunakan data kuantitatif dengan menyebarkan kuesioner yang bersifat terbuka. Jika dilihat dari sumber data, penelitian ini menggunakan data primer yang bersumber dari petani tanaman pangan dan hortikultura sebagai responden. Selain itu, penelitian juga menggunakan data sekunder dari instansi terkait yang relevan sebagai data pendukung. Metode pengumpulan data merupakan langkah yang paling strategis dalam penelitian, karena tujuan utama dari penelitian adalah mendapatkan data. Tanpa mengetahui teknik pengumpulan data, maka peneliti tidak akan mendapatkan data yang memenuhi standar data yang ditetapkan. Dalam penelitian ini menggunakan teknik pengumpulan data sebagai berikut :

a. Studi Kepustakaan (Library Research), metode pengumpulan data ini penulis mencoba mempelajari dan mengkaji berbagai literatur yang berkaitan dengan topik yang akan di teliti, termasuk didalamnya adalah buku-buku, dan jurnal jurnal yang berhubungan dengan penelitian ini.

b. Studi Lapangan (Field Research), metode yang digunakan adalah metode survey dengan menggunakan alat pengumpul data sebagai berikut:

a. Kuesioner, menurut Supranto (2008), merupakan tehnik pengumpulan data yang dilakukan dengan cara memberikan seperangkat pertanyaan atau pernyataan tertulis kepada responden untuk dijawabnya". Bentuk kuesioner yang digunakan dalam penelitian ini bersifat terbuka dimana responden diberikan kebebasan untuk mengisi atau menjawab pertanyaan sesuai dengan kondisi/pengalaman riil yang dialami responden.

b. Wawancara, merupakan metode pengumpulan data dengan cara bertanya langsung (berkomunikasi langsung) dengan responden (Supranto, 2008). Teknik wawancara ini diperlukan penulis terutama untuk menguji kuesioner yang akan digunakan berkaitan dengan apakah pernyataan yang sudah disusun bisa dipahami oleh responden. Wawancara ini dilakukan kepada PPL yang ada dikecamatan di lokasi penelitian dan juga kepada responden untuk mendapatkan informasi yang lebih jauh yang relevan dengan masalah penelitian.

Populasi dalam penelitian ini adalah semua petani sub-sektor tanaman pangan dan hortikultura di kecamatan Muara Sabak Timur. Lokasi penelitian ditentukan dengan sengaja (purposive sampling). Pertimbangan daerah tersebut dijadikan sebagai lokasi penelitian karena kecamatan ini merupakan salah satu dari lima (5) wilayah dengan tingkat produksi/ha (produktivitas) tertinggi dan jumlah masyarakat yang mata pencarian utamanya adalah sub-sektor tanaman pangan dan hortikultura (Dinas Pertanian Tanjung Jabung Timur, 2018). Sedangkan sampel petani yang terpilih untuk diwawancarai adalah yang dipilih secara insidentil acak sederhana atau incidential simple random sampling sebanyak 40 responden.

Variabel yang digunakan dalam suatu penelitian secara konseptual bisa saja sama dengan penelitian yang lain, namun definisi operasinal akan berbeda, tergantung kepada kebutuhan penelitian terutama tujuan penelitian, penggunaan dan ketersediaan serta metode pengumpulan data. Oleh karena itu perlu diberikan definisi operasioanal dari 
setiap variable penelitian. Adapun definisi operasional untuk masing-masing variabel dalam penelitian ini adalah sebagai berikut:

1. Pengeluaran rumah tangga petani adalah seluruh pengeluaran yang dibutuhkan untuk biaya konsumsi dan untuk biaya kegiatan produksi pertanian.

2. Pengeluaran konsumsi adalah biaya yang dikeluarkan untuk memenuhi kebutuhan pokok (konsumsi) yang terdiri dari bahan makanan dan non bahan makanan yang dihitung untuk satu masa tanam dalam satuan rupiah per rumah tangga tani per masa tanam (Rp/RT/MT).

3. Pengeluaran produksi adalah total biaya produksi atau semua korbanan atau biaya yang dikeluarkan dalam proses produksi usaha tani tanama pangan dan hortikultura yang terdiri dari biaya tetap atau totat fixed cost (TFC) dan biaya tidak tetap atau total variable cost (TVC), yang diukur dalam satuan rupiah per rumah tangga tani per masa tanam $(\mathrm{Rp} / \mathrm{RT} / \mathrm{MT})$.

4. Biaya tetap atau totat fixed cost (TFC) adalah biaya yang jumlahnya tidak tergantung dari jumlah produksi serta tidak habis dalam satu kali proses produksi, atau sama dengan biaya penyusutan. Biaya penyusutan dihitung berdasarkan selisih antara harga perolehan (Rp) atau jumlah barang yang dibeli (unit) dikali dengan harga beli barang (Rp/unit) dengan nilai sisa ( $\mathrm{Rp}$ ) dibagi dengan nilai jangka umur ekonomisnya (bulan), seperti biaya peralatan alat pertanian (cangkul, sabit, traktor, dll), yang diukur dalam satuan rupiah per rumah tangga tani per masa tanam (Rp/RT/MT).

5. Biaya tidak tetap atau total variable cost (TVC) adalah biaya yang jumlahnya tergantung dari jumlah produksi dan besarnya dapat berubah tergantung pada tingkat produksi, serta habis dalam satu kali proses produksi, seperti bibit, obat-obatan dan pupuk, upah tenaga kerja, sewa alat, yang diukur dalam satuan rupiah per rumah tangga tani per masa tanam (Rp/RT/MT).

6. Produksi adalah jumlah produk pertanian tanaman pangan dan hortikultura (padi, jagung, kacang-kacangan, sayuran dan buah-buahan) yang dihasilkan dari usaha pertanian, diukur dalam satuan kilogram per rumah tangga per masa tanam $(\mathrm{Kg} / \mathrm{RT} / / \mathrm{MT})$.

7. Harga produksi adalah harga jual produk pertanian tanaman pangan dan hortikultura (padi, jagung, kacangkacangan, sayuran dan buah-buahan) yang diukur dalam rupiah per kilogram $(\mathrm{Rp} / \mathrm{Kg})$.

8. Penerimaan petani adalah total hasil produksi pertanian tanaman pangan dan hortikultura yang dinyatakan dalam ukuran satuan rupiah per rumah tangga per masa tanam (Rp/RT/MT).

9. Pendapatan utama adalah pendapatan petani dari pertanian tanaman pangan dan hortikultura, yang merupakan selisih penerimaan dengan total biaya produksi pertanian tanaman pangan dan hortikultura yang diukur dengan satuan rupiah per rumah tangga per bulan (Rp/RT/MT).

10. Pendapatan sampingan adalah pendapatan rumah tangga tani yang diterima selain dari kegiatan pertanian tanaman pangan dan hortikultura seperti perkebunan, dagang, peternakan dan perikanan, jasa dan lain-lain, yang diukur dengan satuan rupiah per-rumah tangga per masa tanam (Rp/RT/MT).

\section{Alat Analisis}

Metode analisis yang digunakan adalah metode deskriptif. Metode deskriptif adalah prosedur pemecahan masalah yang bertujuan untuk membuat deskripsi atau gambaran secara sistematis, faktual dan akurat terhadap keadaan subjek atau objek dalam penelitian berdasarkan fakta-fakta, sifat-sifat serta hubungan antar fenomena yang diselidiki yang tampak atau apa adanya. Metode ini dianggap relevan dan dapat menjawab tujuan dari penelitian ini. Sejalan dengan metode penelitian, maka alat analisis yang digunakan adalah tabel distribusi frekuensi, grafik dan analisis tabulasi silang (crosstabulation analysis. Selanjutnya untuk menghitung/mengukur Nilai Tukar Petani (NTP) ) subsektor tanaman pangan dan hortikultura digunakan konsep subsisten dengan rumus sebagai berikut:

$\mathrm{NTP}=\frac{\mathrm{PX}_{\mathrm{i}} \mathrm{QX}_{\mathrm{i}}}{\mathrm{PY}_{\mathrm{i}} \mathrm{QY}_{\mathrm{i}}+\mathrm{PY}_{\mathrm{j}} \mathrm{QY} \mathrm{Y}_{\mathrm{j}}}$

dimana: NTS $=$ Nilai Tukar Subsisten; $\mathrm{P}_{\mathrm{Xi}}=$ Harga komoditas pertanian ke i,; $\mathrm{QXi}_{\mathrm{Xi}}=$ Produksi komoditas pertanian ke $\mathrm{i}, ; \mathrm{P}_{\mathrm{Yj}_{\mathrm{j}}}=$ Harga produk konsumsi; $\mathrm{P}_{\mathrm{Yj}}=$ Harga produk input produksi; $\mathrm{Q}_{\mathrm{Yi}}=\mathrm{Jumlah}$ produk konsumsi; $\mathrm{P}_{\mathrm{Yj}_{\mathrm{j}}}=\mathrm{Jumlah}$ input produksi.

\section{Hasil}

Sebelum hasil penelitian disajikan, terlebih dahulu dijelaskan karakteristik petani tanaman pangan dan hortikultura yang menjadi responden dalam penelitian ini. Karakteristik responden meliputi umur, tingkat pendidikan, program yang diterima, jumlah anggota keluarga, luas dan status lahan, jenis tanaman pertanian, pekerjaan sampingan, pendapatan sampingan, dan pendapatan utama (dari tanaman pangan dan hortikultura). Jika dilihat dari umur petani, sebagian besar responden dalam penelitian ini berada pada umur yang produktif yaitu antara berumur antara 26 sampai dengan 55 tahun yaitu sebesar 82,5\%. Sementara responden yang dikategorikan pada usia yang relatif muda yaitu berada pada umur 26 sampai dengan 35 tahun jauh lebih sedikit yaitu sebesar 15\%. Jumlah ini tidak jauh berbeda dengan jumlah responden yang usianya relatif lebih tua (> 56 tahun) yaitu sebesar 17,5\%. Artinya bila dilihat dari faktor usia 
atau umur petani umumnya tergolong usia sangat produktif. Oleh karena itu perlu terus upaya peningkatan produktivitas petani baik melalui workshop dan pelatihan terapan atau pelatihan-pelatihan aplikatif lainnya. Untuk lebih jelasnya karakteristik responden berdasarkan usia dapat dilihat pada tabel 1

Tabel 1

Karateristik Responden Berdasarkan Umur

\begin{tabular}{|c|c|c|c|}
\hline No & Umur & Frekuensi & Persentase (\%) \\
\hline 1 & $26-35$ & 6 & 15 \\
\hline 2 & $36-45$ & 13 & 32.5 \\
\hline 3 & $46-55$ & 14 & 35 \\
\hline 4 & $>56$ & 7 & 17.5 \\
\hline & Total & 40 & 100 \\
\hline
\end{tabular}

Sumber : Data diolah

\section{Karakteristik Responden Menurut Tingkat Pendidikan}

Dilihat dari pendidikan terakhir diketahui bahwa tingkat pendidikan petani yang menjadi responden dalam penelitian ini sebagian besar adalah SLTA kebawah (97,5\%) yang persentasenya hampir sama untuk tiga jenjang pendidikan yaitu pendidikan dasar (SD), pendidikan menengah pertama (SLTP) dan pendidikan menengah atas (SLTA). Sedangkan jumlah petani yang memiliki pendidikan tinggi ( sarjana) masih sangat sedikit yaitu sebesar $2,5 \%$ atau hanya 1 (satu) orang responden. Untuk lebih jelasnya dapat dilihat pada tabel 2 berikut.

Tabel 2

Karakteristik Responden Berdasarkan Tingkat Pendidikan

\begin{tabular}{rlrrr}
\hline & & Tingkat Pendidikan & Frekuensi & Persentase (\%) \\
\hline 1 & SD & 13 & 32,5 \\
2 & SLTP & 14 & 35 \\
3 & SLTA & 12 & 30 \\
4 & Sarjana & 1 & 2.5 \\
& Total & 40 & 100 \\
\hline
\end{tabular}

Sumber : Data diolah

\section{Karakteristik Responden Menurut Program Yang Diterima}

Tanjung Jabung Timur merupakan daerah sentra produksi padi di provinsi Jambi. Sejalan dengan fungsinya tersebut maka pemerintah selalu berusaha untuk meningkatkan produksi pertanian terutama sektor tanaman pangan dan hortikultura melalui beberapa program pemerintah. Tabel 3 berikut ini menunjukkan jumlah petani atau responden berdasarkan program pemerintah yang mereka terima.

Tabel 1

Karakteristik Responden Berdasarkan Program Yang Diterima

\begin{tabular}{llrrr}
\hline & & Program & Frekuensi & Persentase (\%) \\
\hline 1 & LP2B & & - & - \\
2 & GTD & & 14 & - \\
3 & PAJALELE & & - & 35 \\
4 & PATB & 26 & - \\
5 & Non Program & & 40 & 65 \\
& Total & & 100 \\
\hline
\end{tabular}

Sumber : Data diolah

Keterangan: LP2B = Lahan Pertanian Pangan Berkelanjutan; GTD = Gertak Tanpa Dusta; PAJALE = Padi, Jagung dan Kedele; PATB $=$ Perluasan Areal Tanam Baru

Tabel 3 diketahui bahwa terdapat 4 jenis program pemerintah untuk para petani tanaman pangan dan hortikultura di Kabupaten Tanjung Jabung Timur. yaitu program Lahan Pertanian Tanaman Pangan Berkelanjutan (LP2B), Gertak Tanpa Dusta (GTD), Padi, Jagung dan Kedele (PAJALE) dan program Perluasan Area Tanaman Baru (PATB). Dari ke 5 jenis program tersebut, hanya satu jenis program yang diterima oleh petani responden di kecamatan Muara Sabak Timur yaitu program PAJALELE dan ini pun jumlahnya masih sedikit yaitu hanya sebesar $35 \%$. Artinya sebagian besar petani tidak menerima program pemerintah yaitu sebesar $65 \%$ atau sebanyak 26 responden. 


\section{Karakteristik Responden Menurut Jumlah Anggota Keluarga}

Jumlah anggota keluarga petani tanaman pangan dan hortikultura terbanyak (69\%) adalah beranggotakan 3- 4 orang. Ini berarti mereka ummnya hanya memiliki anak satu sampai dua orang saja. Dari Tabel 4 juga dapat dilihat bahwa tidak satupun rumah tangga yang memiliki jumlah anggota keluarga lebih dari 6 orang. Fenomena ini dapat mengindikasikan keberhasilan/suksesnya program Keluarga Berencana (KB) di Kabupaten Tanjung Jabung Timur pada umumnya dan di Kecamatan Muara Sabak Timur pada khususnya. Hal ini juga berarti bahwa masyarakat khususnya petani relatif tingginya kesadarannya terhadap pemahaman besarnya anggota keluarga akan mengakibatkan sulitnya membiayai pendidikan dan kesehatan serta upaya peningkatan kesejahteraan keluarga. Sebagai gambaran jumlah anggota keluarga petani tanaman pangan dan hortikultura dapat dilihat pada table 4 berikut:

Tabel 4

Karakteristik Responden Berdasarkan Jumlah Anggota Keluarga

\begin{tabular}{lcrrr}
\hline & No & Anggota Keluarga & Frekuensi & \multicolumn{2}{c}{ Persentase (\%) } \\
\hline 1 & $<3$ & 5 & 12,5 \\
2 & $3-4$ & 26 & 65 \\
3 & $5-6$ & 9 & 22,5 \\
4 & $>6$ & - & - \\
& Total & & 40 & 100 \\
\hline
\end{tabular}

Sumber : Data diolah

\section{Karakteristik Responden Menurut Luas Lahan}

Salah satu dari aset petani yang menggambarkan potensi pengembangan usaha pertanian adalah distribusi kepemilikan lahan. semakin luas pemilikan akan semakin baik peluang peningkatan produksi dan kesejahteraannya. Kondisi penguasaan lahan yang sempit dan ketimpangan pemilikan lahan menyebabkan kemustahilan petani kecil mampu meningkatkan kesejahteraannya apabila hanya menggantungkan pada mata pencaharian yang berbasis pada lahan. Selama ini definisi petani gurem adalah pemilikan lahan di bawah 0,5 ha. Dengan kriteria tersebut, maka petani yang menjadi responden dalam penelitian ini tidak ada yang masuk dalam kategori petani gurem. Responden yang paling banyak memiliki luas lahan antara 1,00 sampai dengan 1,99 hektar yaitu sebanyak 67,5\%. Apabila lahan usahatani yang dianggap layak dapat memberi pendapatan bagi rumahtangga tani harus lebih dari dua hektar, maka berdasarkan studi ini, maka seharusnya di Kecamatan Muara Sabak Timur cukup banyak petani yang bisa menghidupi keluarga rumahtangga tani dari lahan usahatani. Jumlah responden yang memiliki lahan di atas dua hektar adalah sebanyak 12 responden atau sebesar 30\% sebagaimana terlihat pada Tabel 5 berikut ini.

Tabel 2

Karakteristik Responden Berdasarkan Luas Lahan

\begin{tabular}{lcrrr}
\hline \multicolumn{1}{c}{ No } & Luas Lahan (ha) & Frekuensi & \multicolumn{1}{c}{ Persentase $(\%)$} \\
\hline 1 & $<0,5$ & - & - \\
2 & $0,50-0,99$ & 1 & 2,5 \\
3 & $1,00-1,99$ & 27 & 67,5 \\
4 & $\geq 2,00$ & 12 & 30 \\
& Total & 40 & 100 \\
\hline
\end{tabular}

Sumber : Data diolah

\section{Karakteristik Responden Menurut Status Lahan}

Ada dua bentuk status kepemilikan lahan oleh petani yaitu milik sendiri dan tidak milik sendiri dimana pengusahaan lahannya dapat berupa sewa atau bagi hasil. Berdasarkan hasil survey diketahui bahwa status kepemilikan lahan responden hampir setengahnya tidak milik sendiri (47,5\%), dimana sebagian besar petani yang tidak memiliki lahan sendiri ini statusnya adalah sewa. Kondisi ini tentu dapat mempengaruhi kepada nilai tukar petani dan kesejahteraannya karena mereka haru menanggung biaya produksi yang lebih besar (biaya sewa lahan) dibandingkan mereka yang memiliki lahan sendiri. Jumlah responden berdasarkan status lahan lebih jelasnya dapat dilihat pada table 6 berikut ini.

Tabel 3

Karakteristik Responden Berdasarkan Status Lahan

\begin{tabular}{llrrr}
\hline No & & Status Lahan & Frekuensi & \multicolumn{2}{c}{ Persentase $(\%)$} \\
\hline 1 & Milik Sendiri & & 21 & 52,5 \\
2 & Sewa & & 17 & 42,5 \\
3 & Bagi Hasil & 2 & 5 \\
Total & & 40 & 100 \\
\hline
\end{tabular}

Sumber : Data diolah 


\section{Karakteristik Responden Menurut Jenis Tanaman}

Petani respoden di Kecamatan Muara Sabak Timur pada umumnya menanam jenis tanaman pangan (95\%). Jenis tanaman pangan yang ditanam petani selain padi terdapat juga jagung dan kacang-kacangan (kedele dan kacang tanah) dan untuk hortikultura yang terdiri dari sayuran, jenis tanamannya adalah cabe, mentimun, kacang panjang, sawi, terong, kangkung dan buah-buahannya adalah buah naga dan lengkeng. Dari hasil survey, meskipun jumlahnya sangat sedikit $(2,5 \%)$, diketahui bahwa juga terdapat petani yang tidak hanya mengusahakan satu jenis tanaman saja namun beberapa jenis tanaman pangan dan hortikultura (campuran) dalam waktu bersamaan. Upaya diversifikasi tanaman merupakan salah satu upaya untuk meningkatkan efektifitas dan produkivitas lahan pertanian, oleh karena itu perlu dihimbau agar masyarakat mengupayakan menanam berbagai jenis tanaman yang sesuai dengan lahan mereka masing-masing. Tabel 7 berikut ini menjelaskan karakteristik responden berdasarkan jenis tanaman.

Tabel 4

Karakteristik Responden Berdasarkan Jenis Tanaman

\begin{tabular}{llrrr}
\hline \multicolumn{1}{c}{ No } & & Jenis Tanaman & Frekuensi & Persentase (\%) \\
\hline 1 & Pangan* & & 38 & 95 \\
2 & Hortikultura** & 1 & 2,5 \\
3 & Campuran & & 1 & 2,5 \\
Total & & 40 & 100 \\
\hline
\end{tabular}

Sumber : Data diolah

Keterangan: *Padi, jagung, kedele, kacang tanah; **Cabe, mentimun, kacang panjang, sawi, terong, kangkung; ** Buah naga, lengkeng

\section{Karakteristik Responden Menurut Pekerjaan Sampingan}

Petani responden di Kecamatan Muara Sabak Timur berdasarkan data sampel hampir seluruhnya (95\%) memiliki perkerjaan sampingan dimana pekerjaan sampingannya adalah campuran (65\%). Hal ini terutama dikarenakan mereka penyadari sepenuhnya bahwa jika hanya mengandalkan pendapatan dari perkerjaan utama seperti petani padi. pendapatannya sangatlah tidak mencukupi untuk pemenuhan kebutuhannya. Pekerjaan campuran dimaksud adalah mereka bekerja sebagai petani padi dan juga sebagai buruh, menangkap ikan, dagang dan pekerjaan lainnya. Artinya tergantung pada peluang pekerjaan yang tersedia untuk menambah pendapatan mereka. Namun disisi lain ternyata masih ada sekitar 5\% mereka yang tidak memiliki perkerjaan sampingan atau pekerjaan lain selain dari perkerjaan utama sebagai petani tanaman pangan dan hortikultura. Jika ditelusuri lebih lanjut, didapat pekerjaan sampingan berupa menjadi ketua Rukun Tetangga (RT), menjadi anggota BPD, menjadi guru ngaji, usaha kost-kosan, panggung dan perkerjaan lainnya yang dirangkum dalam kategori pekerjaan lain-lain yang besarnya adalah $7,5 \%$. Untuk lebih jelasnya dapat dilihat pada tabel 8 berikut:

Tabel 5

Karateristik Responden Berdasarkan Pekerjaan Sampingan

\begin{tabular}{|c|c|c|c|}
\hline No & Pekerjaan Sampingan & Frekuensi & Persentase \\
\hline 1 & Perkebunan $^{1}$ & 7 & 17,5 \\
\hline 3 & Perikanan $^{2}$ & 1 & 2,5 \\
\hline 4 & Buruh $^{3}$ & 1 & 2,5 \\
\hline 6 & Campuran & 26 & 65 \\
\hline 7 & Lain-lain ${ }^{4}$ & 3 & 7,5 \\
\hline 8 & Tidak ada & 2 & 5 \\
\hline Total & & 40 & 100 \\
\hline
\end{tabular}

Sumber : Data diolah

Keterangan: 1 Kelapa dalam, sawit, karet pinang; 2 Tambak ikan, cari ikan, nelayan; 3 Buruh tani, pabrik; 4 Aparat desa, guru ngaji, kos-kosan, tukang masak/panggung

\section{Karakteristik Responden Menurut Pendapatan Utama}

Pendapatan utama petani responden sangat beragam. Jumlah pendapatan utama rata-rata adalah Rp. 14.453.162 per masa tanam atau Rp. 3.613.290,5 per bulan jika diasumsi masa tanam rata-rata selam 4 bulan. Dari total responden yang ada, sebanyak 65\% memperoleh pendapatan dibawah rata-rata, dan 50\% dari jumlah tersebut mengalami pendapatan yang minus perbulannya. Petani disamping memperoleh pendapatan dari pekerjaan utamanya, juga menerima pendapatan dari pekerjaan sampingannya. Pekerjaan sampingan ini dapat menambah total pendapatan yang diterima petani. Pendapatan rata-rata dari pekerjaan sampingan adalah sebesar Rp.2.658.667, sehingga menambah pendapatan total rata-rata menjadi sebesar Rp.17.111.828. Dengan meningkatnya pendapatan total responden karena adanya pekerjaan sampingan ini, menyebabkan berkurangnya jumlah responden yang pendapatannya dibawah rerata, 
yakni menjadi $60 \%$ atau berkurang sebesar 5\%. Umumnya petani yang berpendapatan lebih tinggi mereka yang berprofesi sebagai petani tanaman pangan (padi). sementara yang berpendapatan rendah adalah mereka yang berstatus petani hortikultura. Sementara responden yang pendapatannya lebih besar dari rata-ratanya pada umumnya adalah petani yang memilik lahan luas (>2Ha) dan memiliki pekerjaan sampingannya (diluar tanaman pangan dan hortikultura) yaitu yang memiliki kebun karet. Untuk lebih jelasnya dapat dilihat pada table 9 berikut ini.

Tabel 6

Responden Berdasarkan Pendapatan Utama, Pendapatan Sampingan dan Pendapatan Total

\begin{tabular}{lrrr}
\hline Uraian & \multicolumn{3}{c}{$\begin{array}{c}\text { Pendapatan (Rp) } \\
\text { Sampingan }\end{array}$} \\
\hline Rata-rata & 14.453 .162 & 2.658 .667 & \multicolumn{1}{c}{ Total } \\
Minimum & -9.507 .003 & 120.000 & 17.111 .828 \\
Maksimum & 73.426 .152 & 18.750 .000 & -8.507 .003 \\
< Rata-rata (\%) & 65 & 75 & 78.176 .152 \\
> Rata-rata (\%) & 35 & 25 & 60 \\
Minus (\%) & 50 & 6,7 & 40 \\
\hline
\end{tabular}

Sumber : Data diolah

\section{Nilai Tukar dan Penerimaan Petani Tanaman Pangan dan Hortikultura}

Berdasarkan hasil perhitungan dengan menggunakan data hasil survey kepada responden, diperoleh nilai NTP untuk setiap responden sebagaimana terdapat pada tabel 10. Penghitungan NTP dilakukan dengan dua macam konsep yaitu dengan menggunakan konsep penerimaan tani dari tanaman pangan dan hortikultura dan penghitungan NTP dengan menggunakan penerimaan rumah tangga tani (semua penerimaan yang diperoleh petani termasuk yang berasal dari sub-sektor tanaman pangan dan hortikultura juga pendapatan lainnya selain tani. Tabel 10 terlihat bahwa NTP dengan kedua konsep tidak menunjukkan perbedaan yang signifikan. NTP tani rata-rata adalah 1,47045 dan NTP rumah tangga sebesar 1,67339. Jika dilihat dari NTP rata-rata memang cukup baik karena nilainya lebih besar dari 1(satu), namun kalau diperhatikan distribusi nilai NTP untuk setiap responden sangatlah timpang. Jarak antara nilai terendah dan tertinggi NTP tani sangatlah besar, begitu juga untuk NTP rumah tangga. Nilai terendah untuk ke dua konsep NTP sangat kecil sekali yaitu hanya sekitar 0,1 sementara nilai tertingginya adalah sekitar 7 bahkan hampir mendekati 8 . Jika nilai NTP ini dijadikan sebagai indikator kesejahteraan petani, maka dapat dinyatakan bahwa kesejahteraan petani tanaman pangan dan hortikultura di Kecamatan Muara Sabak Timur sangatlah tidak merata. Penyebab dari hal ini dimungkinkan oleh beragamnya status dan luas lahan, jenis tanaman dan jenis pekerjaan sampingan.

Tabel 10

Penghitungan Penerimaan, Konsumsi, Biaya Produksi Dan Nilai Tukar Petani (NTP)

\begin{tabular}{|c|c|c|c|c|c|c|}
\hline $\begin{array}{l}\text { No } \\
(1)\end{array}$ & $\underset{(2)}{\text { Penerimaan Tani }}$ & $\begin{array}{c}\text { Penerimaan Total (RT) } \\
(3)\end{array}$ & $\underset{(4)}{\text { Konsumsi }}$ & Biaya Produksi & $\begin{array}{c}\text { NTP } \\
(6)\end{array}$ & $\begin{array}{l}\text { NTPRP } \\
\text { (7) }\end{array}$ \\
\hline 1 & 108.000 .000 & 110.583 .333 & 7.337 .333 & 40.162 .501 & 2,27369 & 2,32808 \\
\hline 2 & 12.000 .000 & 13.500 .000 & 5.761 .333 & 14.384 .753 & 0,59565 & 0,67011 \\
\hline 3 & 10.000 .000 & 10.350 .000 & 7.470 .667 & 6.260 .281 & 0,72828 & 0,75377 \\
\hline 4 & 6.000 .000 & 7.625 .000 & 3.287 .333 & 43.344 .836 & 0,12867 & 0,16351 \\
\hline 5 & 12.750 .000 & 13.083 .333 & 6.058 .000 & 29.430 .289 & 0,35927 & 0,36867 \\
\hline 6 & 8.000 .000 & 9.000 .000 & 7.338 .000 & 17.507 .003 & 0,32200 & 0,36225 \\
\hline 7 & 25.500 .000 & 27.100 .000 & 9.990 .000 & 48.102 .115 & 0,43896 & 0,46650 \\
\hline 8 & 14.000 .000 & 14.300 .000 & 8.627 .667 & 32.509 .337 & 0,34033 & 0,34762 \\
\hline 9 & 18.000 .000 & 18.250 .000 & 8.118 .000 & 4.718 .111 & 1,40229 & 1,42177 \\
\hline 10 & 9.775 .000 & 10.775 .000 & 6.831 .333 & 11.508 .337 & 0,53300 & 0,58752 \\
\hline 11 & 19.200 .000 & 19.550 .000 & 11.166 .000 & 22.612 .335 & 0,56841 & 0,57877 \\
\hline 12 & 40.800 .000 & 41.575 .000 & 6.628 .000 & 10.679 .002 & 2,35743 & 2,40221 \\
\hline 13 & 1.000 .000 & 20.000 .000 & 12.969 .333 & 21.955 .335 & 0,51540 & 0,57266 \\
\hline 14 & 28.000 .000 & 29.750 .000 & 4.923 .000 & 31.448 .003 & 0,76984 & 0,81796 \\
\hline 15 & 18.000 .000 & 20.850 .000 & 3.491 .667 & 25.133 .892 & 0,62881 & 0,72837 \\
\hline 16 & 16.000 .000 & 23.800 .000 & 19.013 .333 & 5.760 .003 & 0,64586 & 0,96071 \\
\hline 17 & 5.000 .000 & 6.200 .000 & 11.335 .667 & 6.792 .003 & 0,27582 & 0,34202 \\
\hline 18 & 8.000 .000 & 10.450 .000 & 8.406 .333 & 9.936 .669 & 0,43613 & 0,56970 \\
\hline 19 & 24.000 .000 & 28.360 .000 & 5.933 .333 & 6.120 .737 & 1,99103 & 2,35273 \\
\hline 20 & 8.000 .000 & 8.750 .000 & 10.564 .333 & 2.041 .994 & 0,63460 & 0,69410 \\
\hline 21 & 24.000 .000 & 26.200 .000 & 8.387 .667 & 1.928 .438 & 2,32646 & 2,53972 \\
\hline 22 & 6.000 .000 & 24.750 .000 & 10.818 .667 & 3.735 .000 & 0,41227 & 1,70060 \\
\hline 23 & 93.500 .000 & 9.825 .000 & 6.546 .000 & 10.073 .848 & 5,62580 & 5,91161 \\
\hline 24 & 75.000 .000 & 81.300 .000 & 17.319 .333 & 10.836 .558 & 2,66374 & 2,88750 \\
\hline
\end{tabular}




\begin{tabular}{|c|c|c|c|c|c|c|}
\hline 25 & 28.000 .000 & 34.250 .000 & 9.108 .000 & 2.185 .622 & 2,47928 & 3,03269 \\
\hline 26 & 660.000 & 5.660 .000 & 7.300 .667 & 446.444 & 0,08519 & 0,73059 \\
\hline 27 & 5.600 .000 & 6.350 .000 & 12.575 .667 & 1.612 .781 & 0,39469 & 0,44755 \\
\hline 28 & $56,000,000$ & 58.000 .000 & 5.651 .000 & 1.844 .583 & 7,47107 & 7,73789 \\
\hline 29 & 1.400 .000 & 1.400 .000 & 5.785 .000 & 1.075 .694 & 0,20406 & 0,20406 \\
\hline 30 & 1.400 .000 & 1.400 .000 & 9.676 .667 & 1.435 .560 & 0,12599 & 0,12599 \\
\hline 31 & 1.400 .000 & 6.800 .000 & 3.101 .000 & 1.592 .295 & 0,29830 & 1,44888 \\
\hline 32 & 2.250 .000 & 3.950 .000 & 9.632 .000 & 448.056 & 0,22321 & 0,39186 \\
\hline 33 & 1.400 .000 & 2.900 .000 & 6.250 .000 & 1.527 .282 & 0,18001 & 0,37288 \\
\hline 34 & 700.000 & 9.200 .000 & 10.490 .667 & 1.287 .503 & 0,05943 & 0,78111 \\
\hline 35 & 38.250 .000 & 39.800 .000 & 4.768 .667 & 9.762 .000 & 2,63236 & 2,73903 \\
\hline 36 & 52.800 .000 & 53.800 .000 & 12.524 .000 & 4.134.500 & 3,16955 & 3,22958 \\
\hline 37 & 49.440 .000 & 50.940 .000 & 6.168 .000 & 1.314 .667 & 6,60727 & 6,80773 \\
\hline 38 & 32.000 .000 & 32.120 .000 & 6.853 .000 & 1.453 .504 & 3,85240 & 3,86685 \\
\hline 39 & 24.064 .000 & 26.064 .000 & 9.415 .000 & 322.000 & 2,47140 & 2,67680 \\
\hline 40 & 16.000 .000 & 18.250 .000 & 6.723 .333 & 3.338 .667 & 1,59014 & 1,81375 \\
\hline Rerata & 22.972 .225 & 25.630 .892 & 8.358 .625 & 11.269 .063 & 1,47045 & 1,67339 \\
\hline Min & & & & & 0,05943 & 0,12599 \\
\hline Max & & & & & 7,47107 & 7,73789 \\
\hline \multicolumn{2}{|c|}{$\%<$ mean } & & & & $65 \%$ & $62,5 \%$ \\
\hline \multicolumn{2}{|c|}{$\%>$ mean } & & & & $35 \%$ & $37,5 \%$ \\
\hline
\end{tabular}

Sumber : Data diolah

Tabel 10 di atas juga dapat dilihat bahwa penerimaan petani tanaman pangan dan hortikultura di Kecamatan Muara Sabak Timur sangat variatif sekali, baik penerimaan tani maupun penerimaan total. Rata-rata penerimaan total petani adalah Rp. 25.630.892 per-masa tanam sedikit lebih besar dari penerimaan tani yaitu Rp. 22.972.225. Sebanyak $65 \%$ responden memiliki penerimaan tani di bawah rata-rata dan sisanya diatas rata-rata. Untuk persentasi penerimaan total, sedikit lebih banyak petani yang memiliki pendapatan di atas rata-rata yaitu sebesar $37,5 \%$, dan sisanya di bawah rata-rata.

\section{Struktur Pengeluaran Rumah Tangga dan Pola Konsumsi Petani Tanaman Pangan dan Hortikultura}

Struktur pengeluaran rumah tangga petani terdiri dari pengeluaran produksi dan pengeluaran konsumsi. Tabel 11 berikut ini menunjukkan bahwa struktur pengeluaran petani tanaman pangan dan hortikultura untuk pengeluaran produksi lebih besar dibandingkan untuk pengeluaran konsumsi. Proporsi pengeluaran produksi terhadap pengeluaran total adalah sebesar 57,41\% dimana 53,89\% merupakan biaya variabel (bibit, pupuk\&insektisida, biaya tenaga kerja), hanya sebesar 3,53\% saja untuk pengeluaran biaya tetap. Artinya tingkat akumulasi kapitalnya sangat rendah.

Tabel 11

Struktur Pengeluaran Rumahtangga Petani Tanaman Pangan dan Hortikultura di Kecamatan Muara Sabak Timur

\begin{tabular}{|c|c|c|}
\hline No & Uraian & Jumlah \\
\hline \multirow[t]{8}{*}{1} & Struktur Pengeluaran (Rp 000) & \\
\hline & Pengeluaran Produksi & 11.269.063 \\
\hline & - $\quad$ Biaya Variabel & 10.576 .880 \\
\hline & - $\quad$ Biaya Tetap & 692.183 \\
\hline & Pengeluaran Konsumsi & 8.358.625 \\
\hline & Konsumsi Makanan & 4.063 .750 \\
\hline & - $\quad$ Konsumsi Non Makanan & 4.294 .875 \\
\hline & Total pengeluaran & 19.627.688 \\
\hline \multirow[t]{11}{*}{2} & Proporsi Pengeluaran $(\%)$ & \\
\hline & Proporsi Pengeluaran Produksi terhadap Pengeluaran Total & 57,41 \\
\hline & - $\quad$ Proporsi biaya variabel & 53,89 \\
\hline & - $\quad$ Proporsi biaya tetap & 3,53 \\
\hline & Proporsi biaya variabel thdp Total Biaya Produksi & 93,86 \\
\hline & Proporsi biaya tetap thdp Total Biaya Produksi & 6,14 \\
\hline & Proporsi Pengeluaran Konsumsi terhadap Pengeluaran Total & 42,59 \\
\hline & - Proporsi konsumsi makanan & 20,70 \\
\hline & - Proporsi konsumsi non makanan & 21,88 \\
\hline & Proporsi konsumsi makanan thdp Total Konsumsi & 48,62 \\
\hline & Proporsi kons non makanan thdp Total Konsumsi & 51,38 \\
\hline
\end{tabular}


Pola konsumsi petani dapat tergambar dari struktur pengeluaran rumah tangga petani. Setiap rumah tangga memiliki pola konsumsi yang berbeda. Pola konsumsi rumah tangga ini dapat digunakan sebagai indikator untuk menentukan pendapatan rumah tangga serta rumah tangga tersebut. Rumah tangga dengan pangsa konsumsi makanan yang besar menunjukkan bahwa kemampuan rumah tangga tersebut hanya mampu untuk mencukupi kebutuhan makan sehari-hari. Rumah tangga dengan pangsa konsumsi non makanan yang besar menunjukkan bahwa rumah tangga tersebut dapat mencukupi kebutuhan makan anggota keluarganya sehingga dapat membeli kebutuhan lainnya yang tergolong non makanan. Proporsi pengeluaran konsumsi terhadap pengeluaran total adalah sebesar 42,59 \% yang dapat dikelompokkan atas konsumsi makanan dan konsumsi non makanan. Terlihat bahwa pengeluaran konsumsi terhadap non makanan lebih besar dari konsumsi makanan. Rata-rata jumlah konsumsi rumah tangga petani sebesar Rp 8.358.625 per masa tanam. Rata-rata jumlah konsumsi non makanan sedikit lebih besar dari rata-rata jumlah konsumsi makanan, seperti terlihat pada tabel 12 berikut.

Tabel 12

Struktur Pengeluaran Rumahtangga Petani Sabak Timur (Rp/Kap/Bulan)

\begin{tabular}{lrr}
\hline \multicolumn{1}{c}{ Kelompok Barang } & Jumlah Rata-rata Per RT & Persentase $(\%)$ \\
\hline A. Makanan & $\mathbf{4 . 0 6 3 . 7 5 0}$ & $\mathbf{4 8 , 6 2}$ \\
Bahan Makanan & 2.694 .925 & 32,24 \\
Makanan Jadi & 1.368 .825 & 16,38 \\
B. Bukan Makanan & $\mathbf{4 . 2 9 4 . 8 7 5}$ & $\mathbf{5 1 , 3 8}$ \\
Perum. air. listrik & 1.095 .975 & 13,11 \\
Sandang & 459.175 & 5,49 \\
Kesehatan & 446.025 & 5,34 \\
Pend. Rek. OR & 1.099 .525 & 13,15 \\
Transportasi, komunikasi & 1.194 .175 & 14,23 \\
TOTAL & $\mathbf{8 . 3 5 8 . 6 2 5}$ & 100 \\
\hline
\end{tabular}

Sumber : Data diolah

Pengeluaran konsumsi beras masih mendominasi pengeluaran rumah tangga untuk kebutuhan bahan makanan. $\mathrm{Hal}$ ini menunjukkan bahwa sebagian besar rumah tangga petani masih bergantung pada konsumsi beras. Pengeluaran kebutuhan makanan yang lain seperti makanan dan minuman jadi juga memiliki persentase yang cukup besar. Dari hasil wawancara diketahui bahwa jenis barang yang menyumbang paling besar terhadap konsumsi makanan jadi adalah konsumsi rokok yang rutin dibeli oleh para kepala rumah tangga. Secara persentase jumlah responden yang mengkonsumsi rokok relatif kecil namun karena harga rokok mahal dan responden tersebut mengkonsumsi dalam jumlah yang banyak (rerata dua bungkus/hari), sehingga bila diakumulasikan nilainya menjadi besar. Kebutuhan untuk transportasi dan komunikasi di era digital ini juga terjadi pada petani. Hal ini ditunjukkan oleh pengeluaran konsumsi untuk ini proporsinya paling tinggi diantara konsumsi non makanan lainnya seperti perumahan, pakaian, bahkan pendidikan dan kesehatan justru proporsinya sangat kecil. Namun demikian tidak pula otomatis berarti mereka tidak peduli dengan pendidikan dan kesehatan, tetapi ini karena sebagian besar anggota rumah tangga petani yang dalam usia sekolah sangat sedikit dan jika mereka sakit cenderung berobat sendiri atau menggunakan jaminan kesehatan dari pemerintah. Konsumsi non makanan lain yang memiliki persentase yang cukup besar adalah konsumsi biaya listrik dan bahan bakar (gas). Untuk lebih jelasnya dapat dilihat pada tabel 13 berikut ini.

Tabel 13

Struktur Pengeluaran Konsumsi Rumahtangga Menurut Jenisnya

\begin{tabular}{lr}
\hline \multicolumn{1}{c}{ Uraian } & Jumlah \\
\hline Pengeluaran Konsumsi (Rp) & 8.358 .625 \\
Konsumsi Makanan & 4.063 .750 \\
Konsumsi bahan makanan (beras, lauk pauk, bumbu) & 2.694 .925 \\
Konsumsi makanan jadi (susu, roti, rokok, dsb) & 1.368 .825 \\
Konsumsi Non Makanan & 4.294 .875 \\
Konsumsi papan (perumahan), air, listrik & 1.095 .975 \\
Konsumsi sandang (pakaian) & 459.175 \\
Konsumsi kesehatan & 446.025 \\
Konsumsi pendidikan, rekreasi, olahraga & 1.099 .525 \\
Konsumsi transportasi dan komunikasi (pulsa) & 1.194 .175 \\
Proporsi Pengeluaran Konsumsi (\%) & 48,62 \\
Proporsi konsumsi makanan terhadap Total Konsumsi & 32,24 \\
Proporsi konsumsi bahan makanan & 16,38 \\
Proporsi konsumsi makanan jadi & 51,38 \\
Proporsi konsumsi non makanan terhadap Total Konsumsi & 13,11
\end{tabular}




$\begin{array}{lr}\text { Proporsi konsumsi sandang } & 5,49 \\ \text { Proporsi konsumsi kesehatan } & 5,34 \\ \text { Proporsi konsumsi pendidikan, rekreasi,OR } & 13,15 \\ \text { Proporsi konsumsi transportasi \& komunikasi } & 14,32 \\ \text { Proporsi konsumsi terhadap Pengeluaran Total } & 0,29 \\ \text { Proporsi konsumsi bahan makanan } & 6,97 \\ \text { Proporsi konsumsi makanan jadi } & 2,34 \\ \text { Proporsi konsumsi sandang (pakaian) } & 2,27 \\ \text { Proporsi konsumsi kesehatan } & 5,58 \\ \text { Proporsi konsumsi perumahan, air, listrik } & 6,69 \\ \text { Proporsi konsumsi pendidikan, rekreasi,OR } & 6,08 \\ \text { Proporsi konsumsi transportasi dan komunikasi } & \\ \text { Sumer: Datalah }\end{array}$

Sumber : Data diolah

\section{Simpulan}

1. Sebanyak $82,5 \%$ petani tergolong usia sangat produktif. Dari 4 jenis program yang diberikan pemerintah (LP2B, GTD, PAJALE, PATB) hanya satu jenis program yang diterima oleh petani responden yaitu program PAJALELE. Rumah tangga responden sebagian besar beranggotakan 3-4 orang dan tidak ada yang termasuk petani gurem (memiliki lahan < 0,5 ha) dengan status kepemilikan milik sendiri lebih dari 50\%. Jenis tanaman pangan yang ditanam petani adalah padi, jagung dan kacang-kacangan (kedele dan kacang tanah) dan hortikulturanya adalah cabe, mentimun, kacang panjang, sawi, terong, kangkung dan buah-buahannya adalah buah naga dan lengkeng. Hampir semua petani (95\%) mempunyai pekerjaan sampingan sebagai buruh, menangkap ikan, dagang, apparat desa, guru ngaji, usaha kost-kosan, panggung dan lainnya. Pendapatan utama petani responden sangat beragam dengan jumlah rata-rata sebesar Rp. 14.453 .162 per masa tanam atau Rp. 3.613.290,5 per bulan, pendapatan ratarata dari pekerjaan sampingan adalah sebesar Rp.2.658.667, sehingga jumlah pendapatan total rata-rata sebesar Rp.17.111.828.

2. NTP tani (NTP) tidak menunjukkan perbedaan yang signifikan dengan NTP rumah tangga (NTPRP) yaitu masingmasing adalah 1,47045 dan NTP rumah tangga sebesar 1,67339 dengan distribusi nilai NTP untuk setiap responden sangat timpang.

3. Pola konsumsi petani terdiri konsumsi makanan dan konsumsi non makanan dimana rata-rata jumlah konsumsi non makanan lebih besar dari konsumsi makanan. Konsumsi bahan makanan didominasi oleh beras, sementara rokok menyumbang paling besar terhadap konsumsi makanan jadi. Pengeluaran konsumsi untuk transportasi proporsinya paling tinggi diantara konsumsi non makanan lainnya seperti perumahan, pakaian, bahkan pendidikan dan kesehatan justru proporsinya sangat kecil.

\section{Daftar Pustaka}

BPS, Kabupaten Tanjung Jabung Timur. 2014. Data dan Informasi Kabupaten TanjungJabung Timur. Tanjung Jabung Timur (ID): Badan Pusat Statistik Kabupaten Tanjung Jabung Timur.

BPS Badan Pusat Statistik Kabupaten Tanjung Jabung Timur. 2017. Produk Domestik Regional Bruto Kabupaten Tanjung Jabung Timur Menurut Lapangan Usaha 2012-2016. https://tanjabtimkab.bps.go.id/publication/2017/08/07/6f5e81a82d9c25f4e1eef791/produk-domestik-regionalbruto-kabupaten-tanjung-jabung-timur-menurut-lapangan-usaha-2012---2016.html

Dabukke FBM, Iqbal M. 2014. Kebijakan Pembangunan Pertanian Thailand, India, Dan Jepang Serta Implikasinya Bagi Indonesia. AKP. 12(2):87-101.

Daulay A.R., Eka Intan Kumala Putri, Baba Barus, Bambang P. Noorachmat..2016. Analisis Faktor Penyebab Alih Fungsi Lahan Sawah Menjadi Sawit Di Kabupaten Tanjung Jabung Timur. Jurnal Analisis Kebijakan Pertanian, Vol. 14 No. 1, Juni 2016: 1-15.

Esmara, H. 1986. Perencanaan dan Pembangunan Indonesia. Gramedia. Jakarta.

Handewi dkk. Pola Konsumsi dan Pengeluaran Rumah Tangga. Agro-Ekonomika No.2 Tahun XXXIV Oktober 2004. http://www.perhepi.org/ Diakses tanggal 26 Mei 2019.

Kuncoro, Mudrajad. 2004. Masalah Kebijakan dan Politik Ekonomika Pembangunan. PT. Gelora Aksara Pratama. Jakarta

Kuncoro, Sri. 2014. Analisis Pengaruh Pertumbuhan Ekonomi, Tingkat Pengangguran Dan Pendidikan Terhadap Tingkat Kemiskinan Di Provinsi Jawa Timur 2009-2014, Skripsi Sarjana Ekonomi Universitas Muhammadiyah Surakarta.

Mankiw, N. Gregori et all. 2003. Pengantar Ekonomi Edisi Kedua. Jilid 1. Erlangga. Jakarta

Mceachern, William A. 2000. Makro Ekonomi Pendekatan Kontemporer. Salemba Empat. Jakarta

Muchjidin Rachmat. 2013. Nilai Tukar Petani: Konsep,Pengukuran dan Relevansinya Sebagai Indikator Kesejahteraan Petani. Forum Penelitian Agro Ekonomi , Vol.31 No.2, Desember 2013: 111-122. 
Nugroho. 2004. Pembangunan Wilayah: Perspektif Ekonomi, Sosial, dan Lingkungan. LP3ES. Jakarta

Rachmat, M. 2000. Analisa Nilai Tukar Petani Indonesia. Disertasi. Institut Pertanian Bogor.

Riyadh, M.I. 2015. Analisis Nilai Tukar Petani Komoditas Tanaman pangan di Sumatra Utara. Jurnal Ekonomi \& Kebijakan Publik, Vol. 6 No. 1, Juni 201517 - 32 Sumatra Utara.

Roosgandha. E. dan Darwis, Valeriana.2000. Peran Nilai Tukar Petani dan Nilai Tukar Komoditas Dalam Upaya Peningkatan Kesejahteraan Petani Kedelai (Studi Kasus : Provinsi Jawa Timur). Pusat Analisis Sosial Ekonomi dan Kebijakan Pertanian Bogor Badan Litbang Departemen Pertanian.

Sayogyo. 2000. Kemiskinan dan Indikator Kemiskinan. Gramedia.Jakarta.

Sen, Amartya. 2000. Development as Freedom, Oxford University Press, New Delhi.

Sen, Amartya. 1981. Poverty And Famines: An Essay On Entitlement and Deprivation, Clarendon Press, Oxford.

Simatupang, P. 2007. Analisis Kritis Terhadap Paradigma dan Kerangka Dasar Kebijakan Ketahanan Pangan Nasional. Forum Penelitian Agro Ekonomi, 25(1), 1-18.

Sriartha IP, Windia W. 2015. Efektivitas Implementasi Kebijakan Pemerintah Daerah Dalam Mengendalikan Alih Fungsi Lahan Sawah Subak: Studi Kasus Di Kabupaten Badung, Bali. J Kajian Bali. 5(2):327-346.

Syekh. S. 2001, Evaluation of The Rice Production Project in Tanjung Jabung District, Jambi Province, Indonesia; Ph.D Dissertation; Munoz Nueva Ecija Philippine; Unpublished

Supriatna, T. 2000. Strategi Pembangunan dan Kemiskinan: PT.Rineka Cipta. Jakarta

Todaro, M. P. 1989. Economic Development in the Third World. New York \& London Logman.

Tjipherijanto, P. 1997. Prospek Perekonomian Indonesia Dalam Rangka Globalisasi. Rineka Cipta. Jakarta.

UNDP (United Nations Development Programme). 2010. The Real Wealth of Nations: Pathways to Human Development. UNDP, New York.

Zakaria AK, Rachman B. 2013. Implementasi Sosialisasi Insentif Ekonomi Dalam Pelaksanaan Program Perlindungan Lahan Pertanian Pangan Berkelanjutan (PLP2B). FAE. 31(2):139-149. 